Яременко Наталя, кандидат філологічних наук, доцент, доцент кафедри української та світової літератур Криворізький державний педагогічний університет

\title{
СЕНСОРНІ ОБРАЗИ В ХУДОЖНЬО-ЛІТЕРАТУРНІЙ ПРОЕКЦІї ПОВІСТІ Е.-Е.ШМІТТА «ДИТЯ НОЯ»
}

\begin{abstract}
У статті розглянуто специфіку функціонування сенсорних образів у повісті Еріка-Емманюеля Шмітта «Дитя Ноя». Автором відзначено, що ці образи характеризуютъся найвищим ступенем емоційного резонансу $i$ е вагомою складовою психопоетики твору. Спираючисъ на позищію, сбормулъовану в дослідженнях Х.У. Гумбрехта, наголочено на неможливості ігнорувати ставлення до навколишнъого, яке базуетъся на присутності в нъому. Така позиція обумовлена тим, що чуттеве сприйняття предметного світу е первинним базовим механізмом його осягнення людиною. У досліджуваному тексті саме сенсорні (зорові, звукові, тактилъні, олъфакторні, смакові) образи вибудовують смислову модель світу твору та проявляють сутність характеру персонажа, світосприйняття автора. Сенсорні образи розглядатъся як такі, що окреслені їхною предметністю. Вони репрезентують відчуття окремих властивостей навколичнъого, часто виконують роль каталізатора розвитку дій, концентрують увагу на психологічних домінантах персонажа, акцентують на сюжетоутворюючих моментах. При цьому сенсорні конщепти $\epsilon$ суб'єктивними, тому доситъ вілъно інтерпретуютъся. У статті з'ясовано, що особливу роль у повісті відіграють тактильні та олъфакторні образи, які створюють смислові мікрополя у процесі виробництва (продукування) присутності. Звукові та візуалъні кониепти моделюють яскраві музичні та візуалъні екфразиси та реалізуються на всіх рівнях поетики твору. Крім того, завдяки моделюванню системи відчуттевих образів створюетъся потужсний читацъкий емоційний резонанс.
\end{abstract}

Ключові слова: сенсорні образи, продукування
(виробництво) присутності, екфразис, тактилъний
концепт, тілесність.

Yaremenko N. Sensory images in the artistic-literary projection of E.E. Shmitt's story "The child of Noah».

The article deals with the specifics of the functioning of sensory images in Eric-Emmanuel Schmitt's novel "The Child of Noah». The author notes that these images show the highest degree of emotional resonance and it is important component of psychopoetics. Based on the position, 
which was formulated in the research of H. U. Gumbrecht, it emphasizes the impossibility of ignoring the environment, which bases on his presense there. This position is due to the fact, that the sensory perception of the subject world is the main basic mechanism of human's comprehension. There are sensory images (visual, sound, tactile, olfactory, taste), which build a semantic model of the composition's world and show the nature of the character, the worldview of the author in the text. The sensory images were viewed as such as outlined by their physicality. They represent a sense of the individual properties of the environment, it often act as a catalyst for the development of action, focus on the psychological dominance of the character, concentrate on plot-forming moments. At the same time, the sensory concepts are subjective, so they are free to interpret. The article found, that tactile and olfactory images play a huge role and create meaningful microfields in the production of the presence in the story. There are sound and visual concepts which model bright musical and visual exphrasis and realized at all levels of the poetics in composition. In addition, due to the modeling sensory images it creates a powerful reader's emotional resonance.

Key words: sensory images, presence production, exphrasis, tactile concept, physicality.

Постановка проблеми. XX-XXI століття - епоха кардинальних змін, трансформації соціальних, моральних, світоглядних моделей, час, коли людське життя постає як крихка мінлива субстанція, яку в будь-яку мить може зруйнувати черговий катаклізм, сліпа зла воля, а абсолютні цінності піддаються жорсткій критичній переоцінці. У результаті формується тип свідомості, що характеризується трагічністю, схильністю до відстороненості й самоізоляції. Подібні характеристики безумовно відбиваються в превалюванні тенденційного підходу до оцінки естетичних переживань індивідуума, що прагне відродити зв'язки з Універсумом. Слушною видається думка щодо неможливості ігнорувати ставлення до світу, яке базується на присутності в ньому. Утрата тілесності, яка з точки зору Х. У. Гумбрехта постає як результат зміни інформаційного поля, сприяє нівелюванню певних смислових рівнів [4, с. 87]. При цьому соціокультурну реальність, у якій перебуває людина, формують і значення як засіб інтеграції зі світом за допомогою знаків, і присутність як сприйняття предметного середовища. Останнє може обумовлюватися філософською позицією, сформульованою ще Дж. Берклі про те, що існування можливе лише за умови сприйняття: «esse ets percipi».

Людина сучасності, завдячуючи медіатехнологіям, успішно долає часо-просторові бар'єри й усвідомлює, що осягнути присутність можна лише відновивши процес самоідентифікації і подолавши «забуття mілесності» [5]. Апелюючи до М. Хайдеггера, Х. У. Гумберт наголошує, що присутність завжди особистісна, перманентна і плинна. Це і думка про буття, і саме буття. Раптові потрясіння змушують людей помітити, 
що світ хиткий і крихкий, осягнути потребу дослухатися до нюансів і відчути свою присутність в кожній миті: «<..> бути присутнім, значить бути заодно з предметним світом» [4, с. 10]. Феномен тілесності трактується в цьому дослідженні як сукупність сенсорних, вітальних, фізіологічних проявів людського тіла в його єдності зі свідомістю й екзистенційним досвідом, що постає як соціокультурний феномен і реалізується як художня рефлексія на різних рівнях поетикальної організації художньої твору .

Чуттєве сприйняття є первинним базовим механізмом осягнення світу людиною, тому в художньому тексті саме сенсорні (зорові, звукові, тактильні, ольфакторні, смакові) образи вибудовують смислову модель світу твору, проявляють сутність характеру персонажа, світосприйняття автора. Сенсорні образи - це образи окреслені їхньою предметністю, тобто будь-яким зовнішнім по відношенню до суб'єкта фрагментом реальності, що репрезентує відчуття окремих властивостей навколишнього.

Аналіз останніх досліджень та публікацій. Інтерпретація сенсорного досвіду дюдини є актуальною мультидисциплінарною тенденцією. Вивченню цієї проблеми присвячена значна кількість праць з психології. Дослідниками вивчено особливості прояву та взаємодії різномодальних відчуттів людини, віднесених до певних сенсорних систем. У філософському та літературознавому дискурсах діапазон сенсорної образності та її роль у реалізації так званої «інтелектуальної чутливості» (Ф. Кіттлер), розглянуто в дослідженнях Т. Бовсунівської, О. Воробйової, І. Галуцьких, О. Гомілко, І. Редьки та інших науковців. У працях названих учених зокрема зосереджено увагу на художній тілесності як онтологічному феномені, що має багатоплановий характер і розкривається в процесі осягнення когнітивних механізмів художніх текстів, вивчено особливості сенсорної поетики творів у аспекті творення в них полісемантичних відчуттєвих структур.

Творчий доробок Е.-Е.Шмітта, якого масмедіа вважають «серйозним інтелектуалом, що, при цьому не ставиться до себе серйозно» («Lire» у статті «Philosophe clandestin»), є об'єктом дослідження Т. Бовсунівської, А. Білас, Є. Васильєва, М. Логвиненко, Е. Мейєра, О. Чаплінської та інших науковців. Повісті митця чи не найбільш системно розглянуто в напрацюваннях М. Логвиненко. Дослідницею зосереджено увагу на аналізі концептосфери творів «Циклу Незримого», які, на її думку, є началом постгуманістичної прози письменника і репрезентують процес становлення особистості й роль дитинства в цьому процесі [7, с. 112]. 
Рефлексія відчуттєвих образів, їх функціонування в художньому тексті, зокрема в повісті Е.-Е. Шмітта «Дитя Ноя», дозволяе більш повно осягнути шляхи вибудови суб'єктно-об'єктних та суб'єктносуб'єктних (автор-читач) зв'язків між людиною і світом під час моделювання художньої реальності та є лакунарною, що й обумовлює новизну нашого дослідження.

Метою статті є вивчення специфіки функціонування сенсорних образів, для яких характерний найвищий ступінь емоційного резонансу, у повісті Е.-Е. Шмітта «Дитя Ноя».

Виклад основного матеріалу. Сценарист, філософ, драматург, прозаїк, чиї твори перекладено на більш ніж сорок мов світу, митець, що говорить з погляду людини, «зачудованої людством» [11], ЕрікЕмманюель Шмітт є лауреатом безлічі відзнак, зокрема Гонкурівської, Німецької книжкової та премії Французької академії. У центрі нашої уваги повість Е.-Е. Шмітта «Дитя Ноя» («L'enfant de Noe»), яка вийшла друком у 2004 році. Вона входить до своєрідного циклу творів, що їх сам автор в одному з інтерв'ю назвав «Циклом Незримого» [10]. У цих творах, як у своєрідному постсекулярному паломництві митця, його містично-натхненному діалозі з людством, розгортається тема міжрелігійного діалогу, осмислюється можливість творення спільноти, об'єднаної законами вищої моралі.

У досліджуваній повісті йдеться про долю єврейського хлопчика, якому випало суворе випробування в роки німецької окупації. Твір має реальне підгрунтя, присвячений П'єру Перельмутеру, одному із двохсот сімдесяти дітей урятованих від фашистської розправи абатом Андре, вікарієм парафії Іоана Хрестителя в бельгійському містечку Намюрі. Резонуючи з історією легендарного Ноя, епопея порятунку малих іудеїв трансформується в багатопланову метафору: збереження культур, які перебувають під загрозою знищення, далі в нівелювання бінарних опозицій та утвердження ідеї універсальної істини, в основі якої любов до Людини. У повісті автором особливу увагу звернено на специфіку сприйняття беззахисною дитиною загрозливої реальності. Я-оповідач переживає трагедію розлуки з батьками, самотність, страх, невпевненість, сором. У творі митцем особливу увагу приділено тілесним маркерам психічного стану персонажів.

Тактильна сенсорна система є чи не найбільш давньою. Вона максимально оперативно, за допомогою органів чуття та актуалізуючи логічне осмислення, формує уявлення людини про ближній простір. При цьому сенсорні концепти є суб'єктивними, а відтак досить вільно інтерпретуються. Так, у досліджуваній повісті відчуття 
158Літератури світу: поетика, ментальність і духовністъ. 2020. Bип. 14

свіжості свяченої води в католицькому храмі, що її торкнулась рука хлопчика, набуває специфічного внутрішнього наповнення. Страх бути викритим («Це не християнсъка дитина! Нехай вийде!») змінився тактильними відкриттями: «<..> натомість відчув, як від дотику вода сколихнулася, огорнула мою руку $i$ піднллася, прохолодна й чиста, по пальиял угору» $[12$, с. 46]. Образ води тут не лише має чітко виражену конотацію як животворного начала, очищення, а й виступає уособленням зв'язку між земним і небесним.

У пам'яті Жозефа з граничною точністю зринає надзвичайно виразний ейдетичний образ рідної матері. Деталізований спогад містить, в першу чергу, сенсорну інформацію: «Не питайте мене, якою була моя мама: хіба можна описати сонце? Мама випромінювала тепло, силу й padicmъ» $[11$, c. 10]. Образність тактильних концептів дозволяе виписати специфічну духовно-емоційну атмосферу. Наратор транслює стан комфорту й захищеності, які випромінює постать матері, наголошуючи, що у пам'яті збереглися не риси обличчя найріднішої людини, а відчуття, пережиті поблизу неї.

Спілкування Жозефа й Руді з образом Матері Божої також відбувається на візуальному, тактильному, емоційному рівні. Жозеф роздивляється листівки для причастя, торкається їх: «водив пальцем по дорогочінному головному убору, що обрамляв че спокійне обличчя» [12, c.50]. Зовнішній вплив на сенсори сприяв вибудові асоціації й конструюванню цілісного ментального образа матері: «I mym мої очі наповнилися сльозами, я випростався на землі. Руді також. Ми тихо плакали, притискаючи листівки для причастя до серця. Ми думали про наших матерів. Де вони зараз? Чи в ию мить їм так само спокійно, як Маріӥ? Чи ж на їхніх обличчях сяе зараз любов, <.. > а може, на них горе, тривога $і$ безнадія?» [12, с. 50]. Меморативні образи конструюються як результат активізації сенсорних, зокрема тактильних, які безпосередньо пов'язані з пам'яттю. Листівки для причастя, зрештою, виступають носіями екфрастичного зображення. Безмежна ніжність і любов, виписана на ликах Божої Матері, стимулює емоційний відгук у дитячих душах. Автор застосовує дієслівні емотиви «очі наповнилися сльозами», «ми тихо плакали», «на обличчях сяе любов». Подібні конструкти, на думку Н. Коломієць, «<...> дієвим засобом передачі психічних станів та реакиій, вони завдають темпоритм оповіді, підсилюючи емочійне враження від напружених епізодів» [6, с. 54].

Ще одним прикладом яскравого прояву тактильних відчуттів $€$ епізод зустрічі Жозефа з рідними: «Я налетів на батъків $<\ldots>$ мацав, 
гладив і обіймав, тримав їх на місці, не даючи ступити й кроку. Я сто разів повторював ті самі безладні рухи» [12, с. 113]. Нагнітання дієслівного ряду, що передає кінестетичні відчуття, які переживає хлопчик («відчував», «мачав», «гладив», «обіймав», «тримав на місиі $і$ ) динамізують оповідь, дозволяють створити напружену емоційну атмосферу. При цьому персонаж переживає яскраві різномодальні відчуття: «Я був таким щасливим, що мені стало боляче» [12, с. 113]. Багатовимірність відчуттєвого образу засвідчує взаємозв'язок усіх проявів сенсорики персонажа.

Акустичний образ простору в повісті досить виразний і відповідає зображуваній естетичній ситуації. Так, у творі спостерігається розбудова екфразної системи на основі вербального й невербального модусів мислення. Як слушно зауважує Я. Юхимчук, саме реалізація провідних функцій музичного екфразису змушує читача вибудовувати асоціації, переживати нові емоції або відроджувати спогади. Таким чином митець створює ефект «відчиненого вікна», тобто умови, щоб мати можливість споглядати світ за межами простору в якому перебуває реальна людина, осягнути те, що відбувається в інших буттєвих площинах $[14$, с.54]. Автором моделюється своєрідний екфразис духовної музики, що звучить у соборі. У храмі, куди в неділю потрапляє герой, завдяки взаємодії з музикою вибудовується своєрідний діалог персонажа з сакральним: «Стіни завібрували, $i$ це тремтіння стало музикою: заграв орган. Високі ноти лоскотали мені вуха, від низьких спиною пробігали дрижаки. Мелодія розросталася, глибока й велична. I тут за якусь мить я все збагнув: Бог присутній тут. Він - це повітря, що коливаеться, повітря, що співае, повітря, що клубочиться під склепінням, повітря, що вигинається дугою під банею. Він е тим повітрям, що розчиняеться у кольорах вітражів, повітрям, що сяяло, повітрям, що лоскотало, повітрям, що пахло миром, бджолиним воском $і$ солодким ароматом лілеї $<\ldots>$ Я вдихав Бога на повні груди» [12, с. 47]. Наведена розгорнута метафора являє собою складний художній концепт із семантичним центром «Бог». Лексичний повтор не лише актуалізує додаткові смисли, а й «<..> створюе у прозовому творі своєрідний емочійний темпоритм, проявляе особливості авторсъкої позиції» [13, с. 5]. Анафора «він» акцентує на семантичному центрі оповіді. Бог в уяві дитини наповнюе собою простір, постає повітрям, тобто тим, без чого існування неможливе. Лексичний повтор «повітря» виступає корелятом відчуттів персонажа, відбиває його переживання нової реальності, актуалізує ольфакторні образи («пахло миром, бджсолиним 
160Літератури світу: поетика, ментальність і духовністъ. 2020. Bип.14

воском $i$ солодким ароматом лілеї»), що вибудовують стійкі асоціації з теплом, літом, мирним життям, а відтак із безпекою.

На думку С. Журби, «<.. > поєднання виражальних властивостей словесно-образного, зорового, слухового видів творчості сприяе взаємодії та взаємоперехідності синтаксичних, лексико-семантичних тропів та дозволяе митцеві створити власне авторсъку картину світу» [5, с. 153]. Моделювання ж «сенсорно-чуттевого тіла» [3], як когнітивно-семіотичного концепту у творі відбувається шляхом фокусування на окремих рисах персонажа. Слушно стверджує О. Воробйова про те, що використання подібного прийому дозволяє ментально стимулювати читача задля максимального включення його у вир художньої реальності [2, с. 126]. Змальовуючи зустріч Руді, старшого товариша Жозефа, з його матір'ю, що дивом вижила в концентраційному таборі, митець акцентує на її життєвому амплуа, якби наголошуючи, що справжнім джерелом життєвої сили для жінки має стати не «хліб насущний», а мистецтво як духовна субстанція: «Вона похитнулася, однак втримала рівновагу, схопившись за піаніно, на клавіші якого дивилася як на перепону, котру слід подолати» [12, с. 110]. Звуковий ряд завдяки кінестезї набуває рис м'язового відчуття й цілісний сенсорний образ постає як тілесноаудіальна синестезія: «ї̈ руки несміливо наблизилися, а тоді м'яко занурились у слонову кістку. I полинула найніжніша й найпечальніша мелодія з усіх $\langle\ldots>$. Спочатку трохи несмілива $і$ квола, а далі значно багатша й сміливіша музика народжувалася, набирала сили й висоти, вражсала i породжувала відчай» [12, с. 110]. Поступово, наповнюючись фізичною динамікою, моторикою, напруженням м'язів, руки жінки починають взаємодіяти з інструментом, що перед тим сприймався нею як чужий, ворожий («дивилася як на перепону, котру слід подолати») і навіть зливаються з ним («м'яко занурились у слонову кістку»). Метафоричні епітети («квола», «несмілива», «багатша», «сміливіша», «набирала сили й висоти, вражала $i$ породжувала відчай») вибудовують цілісний рельєфний образ музики і надають нових вимірів характеристиці персонажа. В уяві виникають перші мінорні акорди музичного твору, які, посилюючись, наповнюють виконавицю силою й фактично повертають до життя: «Граючи, матір Руді набувала плоті. I тепер я бачив у ній жінку, яку описував Руді. <..> До неї знову поверталися форми, кольори, волосся, владність» [12, с. 110]. Індивідуальний звуковий простір персонажа накладається на семантичне поле тексту повісті й утворює звукову картину світу. 
Візуальні образи у творі відіграють надзвичайно важливу роль, що є цілком логічним, оскільки епіка, з точки зору Д. Наливайка, тяжіє до образотворчого мистецтва, має потребу в досконалому живописанні словом [9, с. 46]. Прикладом може стати епізод знайомства Жозефа з мадемуазель Марсель. Зорове сприйняття і конструювання персонажа дає можливість наратору виписати, на перший погляд, вкрай непривабливий зовні об'єкт: «Вона була схожою на все що завгодно, крім жінки, - ну геть картоплина на пташиному тулубі» [12, с. 30]. Я-оповідач, чиїми очима ми спостерігаємо за персонажем, деталізовано описує риси обличчя жінки-аптекаря: «ї̈̈ обличчя з великими, грубо виліпленими рисами, зі зморщеними повіками, з тъмяною нерівною бугристою землистого відтінку шкірою було схоже на булъбу, обробляючи яку, селянин ударом мотики позначив тонкогубий рот $i$ два невеликі нарости - очі» [12, с. 30]. Соматичні епітети створюють гротескний образ, акцентуючи на його «матеріально-тілесній сутності» (за М. Бахтіним). «Стоячи на худих ногах, подавиисъ уперед, з тулубом, вона, немов вільшанка, стояла, взявшись руками в боки, завівши назад лікті, наче готуючись до злету, і роздивлялася мене перед тим, як клюнути» [12, с. 30]. Оповідач не даремно конкретизує видову характеристику пташки, з якою порівнює жінку. Вільшанка - улюблена пташка британців - має простувату зовнішність, але надзвичайно потужний і привабливий голос, який не поступається солов”їному. Вона уникає інших птахів, любить усамітнюватися, однак може бути приручена людьми. Опис зовнішності мадемуазель Марсель, або як її називають «Чортзабирай», повністю суперечить уявленню про їі вчинки. Кінетичні характеристики («подавшись уперед тулубом», «стояла, взявшись руки в боки», «роздивлялася мене перед тим, як клюнути») свідчать про енергійність, чи навіть агресивність жінки. I далі самохарактеристика персонажа: « $Я$ не добра, я справедлива» [12, с. 32]. Вона стверджує: «Я не люблю кюре, не люблю євреїв, не люблю німиів, але не терплю, коли кривдять дітей» $[12$, с. 32]. Дієслівний повтор «не люблю» окреслює поведінкові пріоритети мадемуазель Марсель, наголошуючи на зухвалості жінки, категоричності її суджень, створюючи хибне уявлення про неї як про особу зверхню й неприємну. При цьому жінка, ризикуючи власним життям, виготовляє підробні документи для єврейських дітей, добуває їм продуктові картки, лікує від різних хвороб. Вона часто діє як підліток: імпульсивно, занадто рішуче, не озираючись назад, вочевидь, зберігши в собі дитинність. Так, дізнавшись про висадку союзних військ наберегах Нормандії, мадемуазель Марсель у соборі на центральній 
площі селища сміливо грає «Уродженку Брабанта» - національний гімн Бельгії. Мелодія цілком співзвучна зі звуковим образом, що його оповідач маркує як «войовничу музику», i, зрештою, спричиняє арешт і страту героїчної жінки.

Висновки. Отже, у повісті Еріка-Емманюеля Шмітта «Дитя Ноя» змодельовано широкий спектр тактильних, звукових, візуальних, ольфакторних образів. Сенсорні концепти часто виконують роль каталізатора розвитку дії, концентрують увагу на психологічних домінантах персонажа, акцентують на сюжетоутворюючих моментах. Особливу роль у повісті відіграють тактильні та ольфакторні образи, що створюють смислові мікрополя у процесі виробництва присутності. Звукові та візуальні концепти моделюють яскраві музичні та візуальні екфразиси, реалізуються на всіх рівнях поетики твору, завдяки ним часто формується його концептуальний простір. Крім того, завдяки моделюванню системи відчуттєвих образів створюється потужний читацький емоційний резонанс.

\section{Література}

1. Екфразис : Вербальні образи мистецтва: монографія / за ред. Т. Бовсунівської. Київ : Київський університет, 2013. 237 с.

2. Воробйова О. П. Поетика хвиль в контексті емоційного резонансу (нарис з когнітивної емотіології). Мова, культура й освіта в сучасному світі / відп. ред. О. А. Стешов. Київ : Вид. центр КНЛУ, 2008. C. $126-135$.

3. Галуцьких І. А. Художня тілесність як конструкт. Нова Філологія. 2014. № 66. С. 61-66.

4. Гумбрехт Х. У. Производство присутствия: Чего не может передать значение /Пер. с англ. С. Зенкина. Москва : Новое литературное обозрение. 2006. 184 c.

5. Журба С. «Вертеп» Аркадія Любченка: музичний контекст. Філологічні студії : Науковий вісник Криворізького державного педагогічного університету. Вип. 15. 2016. С. 151-163.

6. Коломієць Н. Засоби створення атмосфери саспенсу в романі Макса Кідрука «Бот. Гуаякільський парадокс». Літератури світу: поетика, ментальність і духовність. Вип. 13. 2019. С. 52-59.

7. Логвиненко М. Текстовий концепт дитинство в прозі ЕрікаЕммануеля Шмітта: досвід лінгвокогнітивного аналізу Studia linguistika. 2012. Вип. 6 (2). С. 112-119. 
8. Лоуэн А. Предательство тела. Москва : Деловая книга, 1999. 327 с.

9. Наливайко Д. Література в системі мистецтв як галузь компаративістики Літературна теорія і компаративістика. 2-ге вид. Харків : Акта, 2006. С. 31-60.

10. Шмит Э.-Э. Я не постмодернист, я гуманист : Интервью на Радио-свобода. URL : https://www.svoboda.org/a/105942.html (дата последнего посещения: 17.01.20)

11. Ерік-Емманюель Шмітт : «Надаю перевагу темам-табу». URL : http://litakcent.com/2013/04/08/erik-emmanjuel-shmitt-nadajuperevahu-temam-tabu/ (дата звернення: 14.12.19)

12. Шмітт Ерік Емманюель Дитя Ноя : Повість / Переклад 3 французької Зої Борисюк. Львів : Кальварія, 2009. 128 с.

13. Яременко Н. Проза Ю. Яновського, О. Довженка, О. Гончара середини XX ст.: інтенсифікація образності засобом повтору : автореф. дис. ... канд. філол. наук : 10.01 .01 / Дніпропетровськ. Дніпропетровський національний університет ім. О. Гончара. 2003. $20 \mathrm{c}$.

14. Юхимчук Я. Поетика та типологія музичного екфразису у прозі другої половини XX - початку XXI ст. (компаративний аспект) : дис. ... канд.філолог.наук: 10.01.05 / Київ. Інститут літератури ім. Т. Г. Шевченка. 2016. 204 с.

15. Meyer M. Eric-Emmanuel Schmitt ou les identités bouleversées. Paris : Albin Michel, 2004. 160 p. 